\title{
Organizational and Corporate Identity on Social Media: A Literature Review
}

\author{
Stefano Di Lauro ${ }^{1}$, Aizhan Tursunbayeva ${ }^{2}$, Gilda Antonelli ${ }^{3} \&$ Marcello Martinez $^{4}$ \\ ${ }^{1}$ Department of Economics, Management, Institutions, University of Naples Federico II, Italy \\ ${ }^{2}$ eHealth Research Group, University of Edinburgh, UK \\ ${ }^{3}$ Department of Law, Economics, Management and Quantitative Methods, University of Sannio, Italy \\ ${ }^{4}$ Department of Economics, University of Campania “Luigi Vanvitelli”, Italy \\ Correspondence: Stefano Di Lauro, Department of Economics, Management, Institutions, University of Naples \\ Federico II, Italy. E-mail: stefano.dilauro@gmail.com
}

Received: November 30, 2019

doi:10.5539/ijbm.v15n4p53
Accepted: February 11, 2020

Online Published: March 9, 2020

\begin{abstract}
Social media have created a multitude of ways for organizations to develop and disseminate their corporate and organizational identity. However, little is still known about how identity can be observed on social media. To address this research gap, we conducted a scoping review that collected, analyzed and synthesized the corpus of published research on organizational and corporate identity and social media. The analysis presented in this paper provides a description of the state-of-the-art on this topic that we hope can help future scholars to understand the various methodological approaches and types of data most pertinent to the exploration of organizational and corporate identity on social media, even though, overall, it reveals that there are relatively few studies with a reliable and universal method for measuring these concepts. This guarantees that future research will be necessary. Practitioners may also wish to draw on our findings to design more tailored ways of strengthening their organizational and corporate identity.
\end{abstract}

Keywords: corporate identity, literature review, organizational identity, social media

\section{Introduction}

Awareness of the prominence of organizational and corporate identity has increased noticeably in recent years due to the growth of theoretical and empirical work focusing on defining these concepts and the processes associated with them, as well as the outcomes they can lead to (Cornelissen, Haslam, \& Balmer, 2007). Social media have further invigorated discussions around organizational and corporate identity (Gioia, Patvardhan, Hamilton, \& Corley, 2013), as organizations can exist on social media in various ways including official company pages or employees' personal social media profiles. For example, in the social media era every single member of an organization has an equal opportunity to communicate their perception of organizational and corporate identity via personal social media accounts (Dreher, 2014). Diverse scholars have aimed to study the relationship between organizational identity, corporate identity and social media. Their work has revealed the ways organizations can be present on social media (e.g. Devereux, Melewar, \& Foroudi, 2017). They have also shown how diverse social media channels can impact organizations (e.g. Foreman, 2017). A further contribution was to open discussion regarding how organizations can best present their identities on social media for different audiences (e.g. Waters \& Jones, 2011). However, less attention has been paid so far to addressing methodological issues in organizational and corporate identity research (Foreman \& Whetten, 2016) in general and specifically with regard to how this plays out in relation to social media. Indeed, none of the studies surveyed in a recent review on measuring organizational identity had anything of substance to say about how this concept can be measured on social media. Similarly, Melewar (2003) has concluded that, despite significant attention to corporate identity from both academics and practitioners, a definitive understanding of how to analyze the concept does not yet exist. To address these important gaps in the literature, we conducted a review, building on the work of Foreman and Whetten (2016), of the corpus of published research to investigate how organizational and corporate identity can be observed/measured via social media (RQ). This paper will thus identify, analyze and classify existing scholarly evidence on this topic and will offer a synthesis of the current state-of-the-art as a 
point of reference for interdisciplinary scholars exploring novel approaches for measuring organizational and corporate identity, as well as for organizations aiming to understand where they stand in comparison with their competitors and seeking to create effective strategies for managing and/or strengthening their identities.

The paper is organized as follows: in the next section, we briefly review previous relevant research on organizational and corporate identity and social media. Then we describe our methodology for literature search, data extraction, and analysis. This is followed by a discussion of the results of our analysis and conclusions speculating on areas for future research.

\section{Theoretical Background}

Both organizational identity and corporate identity have a myriad of definitions. The original definition of organizational identity in Albert and Whetten (1985) describes it as the way in which members of an organization define themselves as such ("who we are as an organization"). Later scholars claiming that organizational identity is a dynamic concept refined this, complementing it with the question "Who do we want to become?" (He \& Brown, 2013). Nonetheless, most scholars agree that organizational identity has an internal organizational focus and influences the way employees feel about the organizations for which they work (Zollo, Laudano, Boccardi, \& Ciappei, 2019). Employees have a crucial role in organizational processes, as they can project an organizational image (Rho, Yun, \& Lee, 2015) that can affect the perceptions of external stakeholders. In this context, the organizational image that an organization wants to communicate to constituents is often seen as a corporate identity (Cornelissen et al., 2007). Indeed, Westcott Alessandri (2001) analyzed about 20 definitions of corporate identity published between 1977 and 2000 and concluded that corporate identity is the "outward presentation of the firm," and that a steady and good-looking corporate identity will produce a positive organizational image in the eyes of the public. Thus, the terms corporate identity and organizational image are often used interchangeably.

The phrase "Social Media" also has a plethora of definitions. One of the most common refers to it as "a group of Internet-based applications that build on the ideological and technological foundations of Web 2.0, and that allow the creation and exchange of user-generated content" (Kaplan \& Haenlein, 2010, p. 61). The rapid advance of social media has affected numerous organizations around the world. Thus, for example, externally, organizations started using social media to crowdsource innovative ideas about how to improve their service delivery or how to increase transparency regarding their operations (Tursunbayeva, Franco, \& Pagliari, 2017), while internally, organizations started using social media to quickly integrate employees into organizational culture or to increase their engagement by creating a sense of community (Goldwasser \& Edwards 2014). Social media play an increasingly important role in communication and interaction between organizations and their employees, customers, investors, and other internal and external stakeholders (Nguyen \& Sidorova 2018). They have also created a multitude of ways organizations can develop and disseminate their identity (Devereux et al., 2017). Indeed, Gioia and colleagues (2013), in an influential literature review on identity formation and change, confirmed that social media have re-invigorated the discussion about organizational identity.

Previous research on social media and organizational or corporate identity has explored the various ways organizations can exist on social media. These were found to include official means, employee accounts, parody accounts, and online discussions (Devereux et al., 2017). Other relevant studies focused on examining the ways different online media channels can contribute to organizations' projected image, exploring the extent to which it can be claimed that every social media intervention has specific objectives and can deliver explicit benefits to business (Foreman, 2017). Other studies focused on the ways organizations can best present their identities on social media for different audiences. Thus Postman (2008) stressed the importance of graphic elements, such as a logo, to the creation of a corporate identity. Morgan and colleagues (2011) noted that social media have changed the role of the consumer from that of passive recipient to that of active participant, transforming corporate identity from the sending of a message to a process of brand co-creation, in collaboration with consumers on social media (Bruce \& Salomon, 2013). Kuvykaite and Piligrimiene (2013) suggested that overall the way organizations present their identity on social media can vary depending on what strategy is adopted, and that this can include aiming for social media interaction, crafting specific message themes and different forms of content, and the deliberate use of particular social media channels. Although all these studies increase our understanding of how organizational and corporate identity can be developed on social media, they do not, however, greatly enrich our understanding of whether and how we can observe organizational or corporate identity on social media. Indeed, Foreman and Whetten (2016) suggested that most previous organizational identity studies, including literature reviews (e.g., Ashforth, Rogers, \& Corley, 2011; Brown, Dacin, Pratt, \& Whetten, 2006; Corley et al., 2006; Cornelissen et al., 2007; Gioia et al., 2013; Ravasi \& Canato, 2013; Ravasi \& van Rekom, 2003; van Rekom \& van Riel, 2000), focused more on a conceptual perspective, discussing issues and 
terminology, and less on methodological questions. They conducted a systematic literature review analyzing over 80 studies measuring organizational identity, which concluded that there are many approaches to understanding or evaluating organizational identity. These can include "qualitative to quantitative, interpretive to essentialist, deductive to inductive, direct observations to distal proxies, organization-specific dimensions to generalizable types and categories, etc." However, although this review is relatively recent, none of the qualifying studies it analyzed revealed how organizational identity can be measured via social media. Similarly, Melewar (2003) concluded that, despite significant attention from both academics and practitioners to corporate identity, a definitive approach to how to measure the concept does not yet exist, notwithstanding the fact that some previous studies recognized that organizational use of social media is changing identity discourse (Dawson, 2015), providing new perspectives on the concept of identity and suggesting new ways in which the formation of identity works.

Consequently, we aimed to conduct a literature review focused on understanding how organizational and corporate identity can be measured or observed via social media (RQ), and offer it as a helpful reference guide for scholars from diverse disciplines and organizations. In so doing, the review complements existing analyses on measuring organizational (Foreman and Whetten, 2016) and corporate identity (Melewar, 2003) as well as contributing to emerging discourses on the management of identities on social media.

\section{Methodology}

To answer the research question, we undertook a scoping review following the approach first proposed by Arksey and O'Malley (2005), which is widely used to profile emerging topics (e.g. Tursunbayeva, Di Lauro, \& Pagliari, 2018).

A comprehensive search strategy was developed to identify relevant literature. This started with several cycles of piloting interrogations of three international interdisciplinary databases (Scopus, ScienceDirect, and Web of Science) to create a specific and sensitive search query. The search query comprised keywords related to Organizational identity, Corporate identity and Social Media: "Organizational identity" OR "Organisational identity" OR "Organizational image" OR "Organisational image" OR "Corporate identity" AND "Social Media". The references of qualifying studies were also "snowballed" to ensure that no relevant study was missed (Yeager et al., 2014). An email request was sent to the authors of publications not available online or in libraries that the authors had access to.

Following the approach adopted by Foreman and Whetten (2016), the principal criterion for inclusion in this review was that the publication in question attempted to, or proposed a means by which one could, "measure" organizational and corporate identity. Although the term "measure" is defined by the Oxford English Dictionary as "to ascertain the size, amount, or degree of [something] by using an instrument or device marked in standard units", in this review, we see measurement as "any attempt to operationalize and empirically observe [the organizational and corporate identity], including approaches that were more qualitative or abstract" (Foreman \& Whetten, 2016).

One author extracted data from the qualifying studies into a pre-developed Excel spreadsheet. This spreadsheet contained fields related to publication characteristics including author(s), year, title, journal name, and journal discipline. The disciplinary affiliation of journals and study quality were assessed with the help of the Scimago Journal Ranking Portal (2019), following the strategy adopted by Tursunbayeva and colleagues (2018). The results of this analysis were also cross-checked with an analysis of the number of Google Scholar citations. The latter is often used in formal or informal research evaluations and has been shown to be reliable, especially in the Humanities and Social Science disciplines (Martin-Martin et al., 2018). Not all of the qualifying studies were available in Google Scholar, and consequently citations for these studies were not taken into account in the analysis.

We also analyzed social media platforms discussed in the qualifying studies. Finally, we included in our coding scheme three of the six data extraction categories from Foreman and Whetten's (2016) framework for classifying organizational identity measurement approaches including: 1 ) analytical approaches (quantitative and qualitative) and the types of data involved in measuring organizational and corporate identity (i.e. of what kind is the data and how is it analyzed?); 2) identifying whether organizational identity and corporate identity can be operationalized in terms of the views of insiders, outsiders or both (i.e. organizational and corporate identity as seen from whom-which stakeholders?); and 3) unit of analysis (what is the referent?). The remaining three categories were not included as one of these relates to the conceptualization of organizational identity and the other two (use of organizational identity and time frame) were found by Foreman and Whetten (2016) to be rarely included in studies on organizational identity. Finally, we also open-coded (Corbin and Strauss 1990) and 
grouped into emerging categories the findings related to the aspects of corporate and organizational identity that were observable on social media.

\section{Findings and Discussion}

\subsection{Publication Characteristics}

The search strategy yielded 68 publications (Scopus $=35$; Science Direct $=5$; Web of Science $=26$; Snowballed=1; Manually added=1). 37 publications remained after removing 25 duplicates, two descriptions of conference proceedings, one book, and two publications which proved unavailable. 27 scholarly articles qualified for full analysis after the removal of 10 returns which were not relevant for such reasons as that they were not in English or were highly descriptive. Of these 27 studies, 26 were published as journal articles and one as a book chapter. 24 studies were published in unidisciplinary journals (22 in Social Science, one in Information and Communication Technology (ICT) and one in Health) and two in multidisciplinary journals (both Social Science and ICT). The quality of the journals in which these studies were published is in general low-medium (SJR average $=0.836$ ), with the lowest being Problems and Perspectives in Management $(\mathrm{SJR}=0.143)$ and the highest the Journal of Public Relations ( $\mathrm{SJR}=2.313$ ). Overall, the qualifying studies available in Google Scholar have a relatively low number of citations (average 26.7). This may indicate either that research on this topic is still in a nascent state or that new and relevant studies do not build on the theoretical and methodological foundation of the pre-existent studies.

Ozdora-Aksak ( $\mathrm{n}=3$ ) and Atakan-Duman $(\mathrm{n}=2)$, both from Turkey, published the most on the topic of measuring organizational and corporate identity on social media. All the remaining studies were published by various different scholars.

12 studies focused on organizational identity. These derive from the USA, Italy, Denmark, and Norway. 15 studies center on corporate identity or organizational image. One of these, although explicitly referring to organizational identity, was in practice a discussion of the corporate identity perspective. The provenance of corporate identity studies is more internationally various than those conceived in terms of organizational identity, produced in countries like the USA, Belgium, Australia, New Zealand, Canada, the UK, Denmark, South Africa, Portugal, and Turkey.

The earliest of the qualifying studies was published in 2010. However, most of the studies $(n=22)$ were published between 2015-2018.

19 studies mentioned sector or industry of the organizations analyzed. Three of these focused on several sectors together, while the rest dealt with diverse sectors and aimed to measure different types of identity. These sectors comprised Banking ( 3 studies of corporate and 1 of organizational identity), Government and Military (2 studies of corporate and 1 of organizational identity), Health ( 2 corporate identity studies), Education ( 1 corporate and 1 organizational identity study), ICT (1 corporate identity study), Food (1 corporate identity study), Sport (1 corporate identity study), and Art ( 1 organizational identity study). The majority of these 19 studies $(n=10)$ examined a single organization (corporate identity $=6$; organizational identity $=4$ ), six studies examined a group of organizations defined as a sector or cluster (organizational identity $=2$; corporate identity $=4$ ), and three studies examined multiple organizations, with each as a separate entity. The fact that the majority of studies on organizational identity examine a single organization is in line with the findings of Foreman and Whetten (2016) regarding generic research on measuring organizational identity. Detailed information on qualifying studies can be found in Appendix 1.

\subsection{Type of Social Media Studied}

Most of the studies ( $\mathrm{n}=13$ ) addressed social media as a single general phenomenon or grouped several social media platforms together. Five studies used Twitter, four both Twitter and Facebook, one study used LinkedIn, and another single study focused on a social media channel internal to the company in question (see Figure 1). Nevertheless, the findings and discussion sections of almost all the studies relate to social media as a generic type, and in consequence precluded the development of findings and conclusions pertinent to each particular social media channel. 


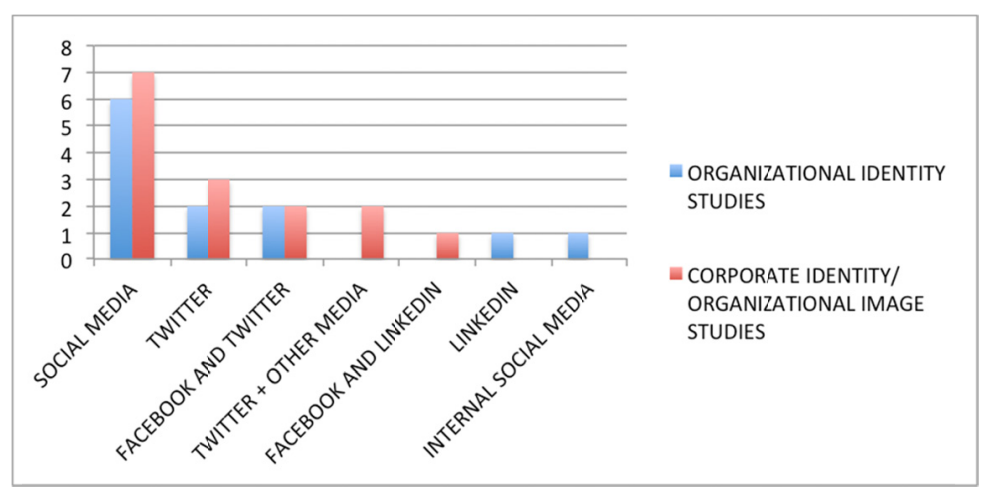

Figure 1. Social media platforms studied

\subsection{What Kind of Data and What Form of Analysis}

10 studies adopted quantitative research design, nine qualitative and five mixed-method, while three studies were conceptual. Interestingly, the majority of studies $(n=7)$ that referred to corporate identity/organizational image were quantitative, while the majority of studies of organizational identity $(n=6)$ were qualitative. These results are in line with the findings of previous research, where many organizational identity studies were found to be of a qualitative nature (Corley \& Gioia, 2004; Ravasi \& Schultz, 2006; Voss, Cable, \& Voss, 2006), and in generally appropriate for emerging research topics due to the opportunity such an approach offers for building theory that can subsequently be tested empirically (Colquitt \& Zapata-Phelan, 2007). Detailed information regarding the type of data analyzed is presented in Figure 2.

Most of the qualitative studies analyzed social media content by means of either interviews or observation by researchers, while most of the quantitative studies analyzed surveys (whether offline or online) (see Appendix 1 for detailed information).

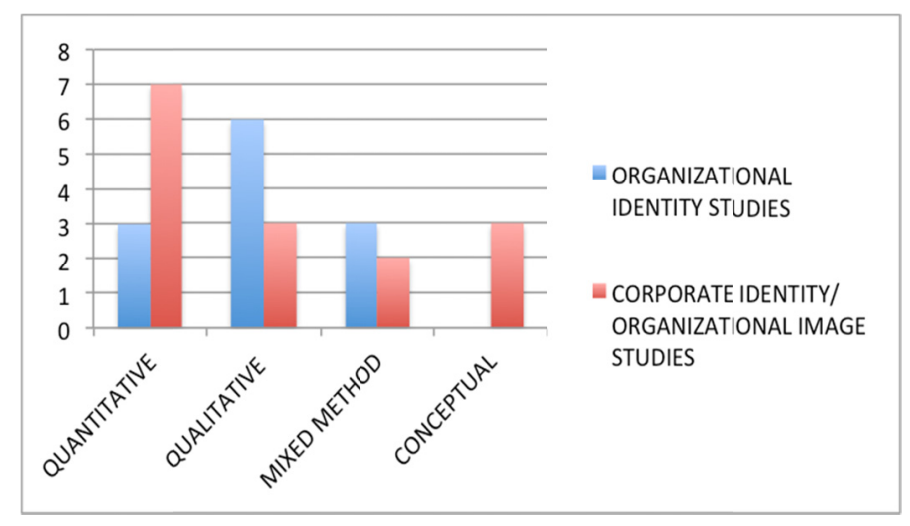

Figure 2. Study design

\subsection{Perspective: Which Stakeholders?}

Our findings illustrate that the majority of corporate identity studies focused on the official social media pages of organizations (e.g. Ozdora-Aksak \& Atakan-Duma, 2015/2016; Joachim et al., 2018). Joackim and colleagues (2018), for example, aimed to understand how companies brand themselves when using Twitter, while Ozdora-Aksak and colleagues (2015) analyzed posts and photos on official company pages so as to identify themes utilized by the companies they studied. Meanwhile, Devereux et al. (2017) underlined how social media can reveal the corporate identity of organizations which choose to use them, summarizing the relationship between corporate identity and social media according to five stages, including adoption, choice of platform(s), choice of content, stakeholder engagement and organization interaction.

Meanwhile, organizational identity has been studied from multiple perspectives (e.g. Dawson, 2018). Nonetheless, almost all the studies we looked at highlighted the role of organizational members in the social 
co-construction of organizational identity, while some specifically recognized the role of employees in this process (e.g. Omilion-Hodges \& Baker, 2014). This, too, accords with previous research reporting on how the use of social media has promoted an ambassadorial role for employees regarding organizational identity and culture. However, some studies also acknowledged the standing of external members such as customers and followers in the management of organizational identity. Dawson (2018), for example, stated that organizational identity should not be limited to internal organizational members, as in some ways it is always defined through its relationship with external stakeholders. For this reason, organizations are recommended to invest in endorsing social media interaction among diverse stakeholders (Nguyen \& Sidorova, 2018).

\subsection{Corporate Identity and Social Media}

Two major themes emerged from our analysis of how corporate identity can be observed on social media, that of positive corporate image (e.g. Hussain, 2015), and that of corporate values (Ozdora-Aksak \& Atakan-Duma, 2014).

The positive nature of corporate image was mentioned in studies in relation to the rapidity of information sharing (Holmgreen, 2015; Joachim et al., 2018), as well as the ability of social media to help organizations to maintain and protect a strong reputation (Oliveira \& Figueira, 2015). Thus, for example, the research conducted on the whole population of Higher Polytechnic Portuguese Education Institutions revealed that it is important to invest heavily in communicating corporate identity via social media in order to create and maintain a positive corporate image, both internally and externally (Oliveira \& Figueira, 2015). Creating a dialogue with stakeholders on social media was identified as another crucial element in developing, co-constructing or enhancing corporate image (e.g. Pang et al., 2018). Moreover, some of the studies we examined revealed that a positive impact of social media on corporate identity can be achieved by using some simple strategies. These include instilling trust and confidence in customers, creating a memorable and lasting impression on every encounter (Boateng \& Okoe, 2015), and, overall, ensuring that corporate identity is in sync with the image desired by diverse stakeholders (Bruce \& Solomon, 2013).

"Corporate values" are the dominant system of beliefs and moral principles that are intrinsic to an organization and its purpose (Campbell \& Yeung, 1991). Ozdora-Aksak and Atakan-Duma (2014), in line with generic corporate identity research, underline that corporate values can motivate stakeholders to support organizations and suggest some themes that can be used to construct and communicate corporate identities on social media such as being ethical or being the highest, strongest and/or the first. Correspondingly, Brandhorst and Jennings (2016) report the case of Planned Parenthood, a nonprofit organization that provides sexual health care in the US and globally, and which uses Twitter hashtags as a call for unity among supporters, reminding them what the organization stands for and promotes - "important American values".

\subsection{Organizational Identity and Social Media}

As aforementioned, organizational identity has been studied from multiple perspectives. However, most of the studies focused primarily on the role of organizational members in the social co-construction of organizational identity on internal or external social media channels. Thus Madsen's (2016) study reported specifically that coworkers can contribute to the construction of organizational identity when they discuss and negotiate organizational identity on internal social media. In consequence, the study highlights the importance of treating all employees as essential partners in the management of organizational identity (Omilion-Hodges \& Baker, 2014). Moreover, organizations are also advised to create a strong internal brand on internal social media which can increase the extent to which employees identify with the organization for whose image they are partly responsible (Omilion-Hodges \& Baker, 2014).

Meanwhile, Albu and Etter's work (2016) stresses the importance of interaction and engagement on external social media such as Twitter for building organizational identity and co-constituting the desired representation of the organization. This study also suggests that the use of hashtags on external social media can only help to co-produce organizational identity insofar as it also renders possible its destabilization by people external to the organization if used incorrectly. For example, during the corporate sustainability campaign of a multinational fast-food chain, an activist NGO "took over" the hashtag created by the company account for raising awareness of its socially responsible supply chain activities, by linking it with the unsustainable ingredients used in the company's food products).

Lastly, Ozdora Aksak and Aktakan Duman's case study (2016), which explores how a Turkish bank uses corporate social responsibility to construct its identity, reveals that all organizational communication channels, including internal and external social media, have a role to play in constructing a competitive, legitimate and moral organizational identity, and communicating it to all stakeholders. 


\section{Conclusion}

Interest in social media has increased in the last few years considering their high adoption rates, as well as the power they have given to organizations and individuals to interact with each other. Scholars and practitioners published numerous recommendations for effective social media communication or management strategies including how social media can be used to communicate or manage organizational or corporate identity. The former has been illustrated for example by recent generic reviews on social media metrics and analytics in marketing (e.g. Misirlis and Vlachopoulou, 2018) or generic reviews on advances in social media research (e.g. Kapoor et al., 2017). Regardless of this interest, little attention has been dedicated so far to addressing methodological issues in organizational and corporate identity research, in particular how these concepts can be measured or observed either in general or specifically on social media.

This study set out to collect, analyze and synthesize the corpus of published research on approaches to observing/measuring organizational and corporate identity on social media. Our work makes several important contributions to the existing organizational and corporate identity research. Our findings provide an overview of the state-of-the-art of organizational identity, corporate identity and social media research including an in-depth overview of publication characteristics and associated literature gaps. They show that this research is in a nascent state; that most of the studies on exploring organizational and corporate identity on social media come from high-income countries; that recent studies do not draw to a great extent on previous organizational/corporate identity and social media research, and that they mostly employ the generic category "social media," making it difficult to draw particular conclusions for each specific platform. Those few studies that specify which social media platforms they considered focus mostly on Facebook and Twitter, with the result that LinkedIn is under-researched, despite the fact that it is one of the most popular professional social media platforms, on which users are integrated largely on the basis of their professional position and relationships (Baccarella, Wagner, Kietzmann, \& McCarthy, 2018). It also means that the latest social media channels such as Instagram or Snapchat are neglected. Moreover, we have observed that there is some confusion about definitions, as some studies use the terms "organizational identity" and "corporate identity" interchangeably. This may indicate that authors are tending tacitly to shape these two concepts to fit their ontological and epistemological assumptions about the organizations they study (Dowling, 2016; Foreman, \& Whetten, 2016).

Overall, even though our review touches on and analyzes diverse studies focusing on several different aspects of measurement of corporate and organizational identity on the basis of social media or tools that can be used on diverse social media, it has not found much in the way of a reliable and standard method for measuring them, whether because of the ambiguity of these concepts or because developing such a standard is a demanding task (Melewar, Karaosmanoglu, \& Paterson, 2005). Our findings should be of interest to interdisciplinary scholars nonetheless, for example, in making them aware of methodological approaches and types of data so far used to explore organizational and corporate identity. One consequence might be that future scholars see the value of developing more sophisticated research designs that take into account previous research which has drawn attention to the disadvantages of the prevailing tendency to study organizational identity in isolation from other matters. Complex research designs could enable the simultaneous and coordinated study of both internal and external perspectives for measuring and observing organizational and corporate identity (Navis \& Glynn, 2010), including attention to how organizational identity can emerge from the social media profiles and activity of employees.

These research designs might also be longitudinal, and test empirically, in organizations from diverse sectors, whether and how corporate and organizational identity can be observed with reference to not only positive corporate image and corporate values, but also how organizational identity can be gauged with the help of hashtags on external social media and employees' discussions on internal social media - in other words, employing the categories that have emerged from our analysis.

This study also has important practical implications for managers. Organizations investing in social media and in promoting both their products and themselves as an employer should be interested in exploring what kind of results these efforts have achieved. Drawing on these findings organizations will be able to design more tailored interventions for strengthening the management of their organizational and corporate identity on social media, and thus to promote successful organizational performance (Voss et al., 2006). 


\section{References}

Albert, S., \& Whetten, D. (1985). Organizational identity. In L. Cummings \& B. Staw (Eds.), Research in Organizational Behavior (Vol. 1 No. 7, pp. 263-295). Greenwich: JAI Press.

Albu, O., \& Etter, M. (2016). Hypertextuality and Social Media: A Study of the Constitutive and Paradoxical Implications of Organizational Twitter Use. Management Communication Quarterly: McQ, 30(1), 5. https://doi.org/10.1177/0893318915601161

Arksey, H., \& O’Malley, L. (2005). Scoping studies: towards a methodological framework. International Journal of Social Research Methodology, 8(1), 19-32. https://doi.org/10.1080/1364557032000119616

Ashforth, B., Rogers, K. M., \& Corley, K. (2011). Identity in organizations: Exploring cross-level dynamics. Organization Science, 22(5), 1144-1156. https://doi.org/10.1287/orsc.1100.0591

Baccarella, C. V., Wagner, T. F., Kietzmann, J. H., \& McCarthy, I. P. (2018). Social media? It's serious! Understanding the dark side of social media. European Management Journal, 36(4), 431-438. https://doi.org/10.1016/j.emj.2018.07.002

Boateng, H., \& Okoe, A. (2015). Consumers' attitude towards social media advertising and their behavioural response: The moderating role of corporate reputation. Journal of Research in Interactive Marketing, 9(4), 299-312. https://doi.org/10.1108/JRIM-01-2015-0012

Brandhorst, J., \& Jennings, F. (2016). Fighting for funding: Values advocacy and Planned Parenthood's right-to-life. Public Relations Review, 42(4), 723-733. https://doi.org/10.1016/j.pubrev.2016.06.002

Brown, T. J., Dacin, P. A., Pratt, M. G., \& Whetten, D. A. (2006). Identity, Intended Image, Construed Image, and Reputation: An Interdisciplinary Framework and Suggested Terminology. Journal of the Academy of Marketing Science, 34(2), 99-106. https://doi.org/10.1177/0092070305284969

Bruce, M., \& Solomon, M. (2013). Managing for Media Anarchy: A Corporate Marketing Perspective. Journal of Marketing Theory and Practice, 21(3), 307-318. https://doi.org/10.2753/MTP1069-6679210305

Campbell, A., \& Yeung, S. (1991) Creating a sense of mission. Long Range Planning, 24, 10-20. https://doi.org/10.1016/0024-6301(91)90002-6

Carpentier, M., Van Hoye, G., Stockman, S., Schollaert, E., Van Theemsche, B., \& Jacobs, G. (2017). Recruiting nurses through social media: Effects on employer brand and attractiveness. Journal of Advanced Nursing, 73(11), 2696-2708. https://doi.org/10.1111/jan.13336

Corbin, J., \& Strauss, A. (1990). Grounded Theory Research: Procedures, Canons, and Evaluative Criteria. Qualitative Sociology, 13(1). https://doi.org/10.1007/BF00988593

Corley, K. G., \& Gioia, D. A. (2004). Identity Ambiguity and Change in the Wake of a Corporate Spin-off. Administrative Science Quarterly, 49(2), 173-208. https://doi.org/10.2307/4131471

Corley, K. G., Harquail, C. V., Pratt, M. G., Glynn, M. A., Fiol, C. M., \& Hatch, M. J. (2006). Guiding Organizational Identity Through Aged Adolescence. Journal of Management Inquiry, 15(2), 85-99. https://doi.org/10.1177/1056492605285930

Cornelissen, J., Haslam, S., \& Balmer, J. (2007). Social Identity, Organizational Identity and Corporate Identity: Towards an Integrated Understanding of Processes, Patternings and Products. British Journal of Management, 18(s1), S1-S16. https://doi.org/10.1111/j.1467-8551.2007.00522.x

Dawson, V. R. (2015). "Who are we online?" Changing perspectives toward organizational identity in social media context. The Journal of Social Media in Society, 4(2), 3-47.

Dawson, V. (2018). Fans, Friends, Advocates, Ambassadors, and Haters: Social Media Communities and the Communicative Constitution of Organizational Identity. Social Media and Society, 4(1). https://doi.org/10.1177/2056305117746356

Devereux, L., Melewar, T., \& Foroudi, P. (2017). Corporate Identity and Social Media: Existence and Extension of the Organization. International Studies of Management \& Organization, 47(2), 110-134. https://doi.org/10.1080/00208825.2017.1256161

Di Lauro, S., Tursunbayeva, A., Antonelli, G., \& Martinez, M. (2018). Measuring organizational identity via LinkedIn: The role played by employees' tenure, type of employment contract and age. Studi Organizzativi, 2, 114-129. https://doi.org/10.3280/SO2018-002005

Dowling, G. R. (2016). Defining and Measuring Corporate Reputations. European Management Review, 13(3), 
207-223. https://doi.org/10.1111/emre.12081

Dreher, S. (2014). Social media and the world of work. A strategic approach to employees' participation in social media. Corporate Communications: An International Journal, 19(4), 344-356. https://doi.org/10.1108/CCIJ-10-2013-0087

Foreman, C. (2017). 10 Types of Social Media and How Each Can Benefit Your Business. In Hootsuite Social Blog. https://blog.hootsuite.com/types-of-social-media/

Foreman, P., \& Whetten, D. (2016). Measuring Organizational Identity: Taking stock and looking forward. In (Ed.), The Oxford Handbook of Organizational Identity. Oxford University Press. https://doi.org/10.1093/oxfordhb/9780199689576.013.3

Foreman-Wernet, L. (2017). Reflections on Elitism: What Arts Organizations Communicate About Themselves. Journal of Arts Management Law and Society, 47(4), 274-289. https://doi.org/10.1080/10632921.2017.1366380

Gilpin, D. (2010). Organizational Image Construction in a Fragmented Online Media Environment. Journal of Public Relations Research, 22(3), 265-287. https://doi.org/10.1080/10627261003614393

Gioia, D., Patvardhan, S., Hamilton, A., \& Corley, K. (2013). Organizational identity formation and change. Academy of Management Annals, 7, 123-193. https://doi.org/10.1080/19416520.2013.762225

Goldwasser, C., \& Edwards, M. L. (2014). Change 3.0: using social media to engage your workforce. Performance, 6(1), 46-53

Hanusch, F. (2017). Political journalists' corporate and personal identities on Twitter profile pages: A comparative analysis in four Westminster democracies. New Media \& Society, 20(4), 1488-1505. https://doi.org/10.1177/1461444817698479

Holmgreen, L. (2015). Why am I to blame when the law is on my side? A study of crises, public opinion and frames. On the Horizon, 23(4), 363-373. https://doi.org/10.1108/OTH-01-2015-0001

Huang-Horowitz, N., \& Freberg, K. (2016). Bridging organizational identity and reputation messages online: a conceptual model. Corporate Communications, 21(2), 195-212. https://doi.org/10.1108/CCIJ-06-2014-0034

Hussain, S. B. (2015). The impact of social media within the sporting industry. Problems and Perspectives in Management, 13(4), 223-229.

Joachim, J., Martin, M., Lange, H., Schneiker, A., \& Dau, M. (2018). Twittering for talent: Private military and security companies between business and military branding. Contemporary Security Policy, 39(2), 298-316. https://doi.org/10.1080/13523260.2017.1420608

Kaplan, A. M., \& Haenlein, M. (2010). Users of the world, unite! The challenges and opportunities of Social Media. Business Horizons, 53(1), 59-68. https://doi.org/10.1016/j.bushor.2009.09.003

Kapoor, K. K., Tamilmani, K., Rana, N. P., Patil, P., Dwivedi, Y. K., \& Nerur, S. (2018). Advances in Social Media Research: Past, Present and Future. Information Systems Frontiers, 20(3), 531-558. https://doi.org/10.1007/s10796-017-9810-y

Kuvykaitè, R., \& Piligrimienè, Ž. (2013). Communication in social media for company's image formation. Economics and Management, 18(2). http://dx.doi.org/10.5755/j01.em.18.2.4651

Madsen, V. (2016). Constructing organizational identity on internal social Media: A case study of coworker communication in Jyske Bank. International Journal of Business Communication, 53, 220-223. https://doi.org/10.1177/2329488415627272

Martín-Martín, A., Orduna-Malea, E., Thelwall, M., \& Delgado López-Cózar, E. (2018). Google Scholar, Web of Science, and Scopus: A systematic comparison of citations in 252 subject categories. Journal of Informetrics, 12(4), 1160-1177. https://doi.org/10.1016/j.joi.2018.09.002

Melewar, T. C. (2003). Determinants of the corporate identity construct: a review of the literature. Journal of Marketing Communications, 9(4), 195-220. https://doi.org/10.1080/1352726032000119161

Melewar, T. C., Karaosmanoglu, E., \& Paterson, D. (2005). Corporate identity: concept, components and contribution. Journal of General Management, 31(1), 59-81. https://doi.org/10.1177/030630700503100104

Melián-González, S., \& Bulchand-Gidumal, J. (2016). Worker word of mouth on the internet: Influence on human resource image, job seekers and employees. International Journal of Manpower, 37(4), 709-723. https://doi.org/10.1108/JJM-09-2014-0188 
Misirlis, N., \& Vlachopoulou, M. (2018). Social media metrics and analytics in marketing - S3M: A mapping literature review. International Journal of Information Management, 38(1), 270-276. https://doi.org/10.1016/j.ijinfomgt.2017.10.005

Montanari, F., Codeluppi, E., \& Scapolan, A. (2013). Identity and Social Media in an Art Festival. In Tourism Social Media: Transformations in Identity, Community and Culture (Vol. 18, pp. 207-225). Emerald Group Publishing Limited. https://doi.org/10.1108/S1571-5043(2013)0000018014

Morgan, N., Jones, G., \& Hodges, A. (2011). The Complete Guide to Social Media from the Social Media Guys.

Nguyen, Q., \& Sidorova, A. (2018). Organizational Identification and User Responses to Online Organization Criticism. Journal of Computer Information Systems. https://doi.org/10.1080/08874417.2017.1405295

Oliveira, L., \& Figueira, Á. (2015). Benchmarking Analysis of Social Media Strategies in the Higher Education Sector. Conference on ENTERprise Information Systems/International Conference on Project MANagement/Conference on Health and Social Care Information Systems and Technologies, 64, 79-786. https://doi.org/10.1016/j.procs.2015.08.628

Omilion-Hodges, L., \& Baker, C. (2014). Everyday talk and convincing conversations: Utilizing strategic internal communication. Business Horizons, 57(3), 435. https://doi.org/10.1016/j.bushor.2014.02.002

Ozdora-Aksak, E. (2015). An analysis of Turkey's telecommunications sector's social responsibility practices online. Public Relations Review, 41(3), 365. https://doi.org/10.1016/j.pubrev.2015.01.001

Ozdora-Aksak, E., \& Atakan-Duman, S. (2015). The online presence of Turkish banks: Communicating the softer side of corporate identity. Public Relations Review, 41(1), 119. https://doi.org/10.1016/j.pubrev.2014.10.004

Ozdora-Aksak, E., \& Atakan-Duman, S. (2016). How a Turkish bank uses corporate social responsibility to construct its identity? A case study. University Faculty of Communication Journal, (50), 73-87.

Pang, A., Shin, W., Lew, Z., \& Walther, J. (2018). Building relationships through dialogic communication: organizations, stakeholders, and computer-mediated communication. Journal of Marketing Communications, 24(1), 68-82. https://doi.org/10.1080/13527266.2016.1269019

Postman, J. (2008). SocialCorp: Social media goes corporate. New Riders Publishing. Indianapolis, USA.

Rasmussen, J. (2017). “Welcome to Twitter, @CIA. Better late than never”: Communication professionals' views of social media humour and implications for organizational identity. Discourse and Communication, 11(1), 89-110. https://doi.org/10.1177/1750481316683295

Ravasi, D., \& Canato, A. (2013). How Do I Know Who You Think You Are? A Review of Research Methods on Organizational Identity. International Journal of Management Reviews, 15(2), 185-204. https://doi.org/10.1111/ijmr.12008

Ravasi, D., \& Schultz, M. (2006). Responding to Organizational Identity Threats: Exploring the Role of Organizational Culture. The Academy of Management Journal, 49(3), 433-458. https://doi.org/10.5465/amj.2006.21794663

Ravasi, D., \& van Rekom, J. (2003). Key Issues in Organizational Identity and Identification Theory. Corp Reputation Rev, 6, 118. https://doi.org/10.1057/palgrave.crr.1540194

Rho, E., Yun, T., \& Lee, K. (2015). Does Organizational Image Matter? Image, Identification, and Employee Behaviors in Public and Nonprofit Organizations. Public Administration Review, 75(3), 421-431. https://doi.org/10.1111/puar.12338

Scimago Journal ranking portal, Scimago Journal \& Country Rank (2019).

Tursunbayeva, A., Di Lauro, S., \& Pagliari, C. (2018). People analytics-A scoping review of conceptual boundaries and value propositions. International Journal of Information Management, 43, $224-247$. https://doi.org/10.1016/j.ijinfomgt.2018.08.002

Tursunbayeva, A., Franco, M., \& Pagliari, C. (2017). Use of social media for e-Government in the public health sector: A systematic review of published studies. Government Information Quarterly, 34(2), $270-282$. https://doi.org/10.1016/j.giq.2017.04.001

Van Rekom, J., \& Van Riel, C. (2000). Operational Measures of Organizational Identity: A Review of Existing Methods. Corp Reputation Rev, 3, 334. https://doi.org/10.1057/palgrave.crr.1540124

Voss, Z., Cable, D., \& Voss, G. (2006). Organizational Identity and Firm Performance: What Happens When 
Leaders Disagree About "Who We Are?" Organization Science, 17(6), 741-755. Retrieved from http://www.jstor.org/stable/25146074

Waters, R., \& Jones, P. (2011). Using video to build an organization's identity and brand: A content analysis of nonprofit organizations' youtube videos. Journal of Nonprofit and Public Sector Marketing, 23(3), 248-268. https://doi.org/10.1080/10495142.2011.594779

Westcott, A. S. (2001). Modeling corporate identity: A concept explication and theoretical explanation. Corporate Communications: An International Journal, $\quad 6(4), \quad$ 173-182. https://doi.org/10.1108/EUM0000000006146

Yeager, V. A., Menachemi, N., Savage, G. T., Ginter, P. M., Sen, B. P., \& Beitsch, L. M. (2014). Using resource dependency theory to measure the environment in health care organizational studies: a systematic review of the literature. Health Care Management Review, 39(1), 50-65. https://doi.org.10.1097/HMR.0b013e3182826624.

Zollo, L., Laudano, M. C., Boccardi, A., \& Ciappei, C. (2019). From governance to organizational effectiveness: the role of organizational identity and volunteers' commitment. Journal of Management and Governance, 23, 11-137. https://doi.org/10.1007/s10997-018-9439-3

\section{Appendix 1. Characteristics of studies meeting the inclusion criteria}

\begin{tabular}{|c|c|c|c|c|c|c|c|c|c|c|}
\hline Author(s), year & Title & $\begin{array}{c}\text { Number } \\
\text { of } \\
\text { citations }\end{array}$ & Main focus & Country & Sector & Study aim & $\begin{array}{l}\text { Analytical } \\
\text { approaches }\end{array}$ & $\begin{array}{c}\text { Research design/ } \\
\text { measurement } \\
\text { methods }\end{array}$ & Research participant/s & $\begin{array}{l}\text { Unit of } \\
\text { Analysis }\end{array}$ \\
\hline Albu \& Etter, 2016 & $\begin{array}{l}\text { Hypertextuality and Social } \\
\text { Media: A Study of the } \\
\text { Constitutive and } \\
\text { Paradoxical Implications } \\
\text { of Organizational Twitter } \\
\text { Use }\end{array}$ & 31 & $\begin{array}{l}\text { Organizational } \\
\text { identity }\end{array}$ & $\mathrm{NA}$ & $\begin{array}{l}\text { Advocacy, banking, } \\
\text { tourism, food }\end{array}$ & $\begin{array}{l}\text { How two organizations used } \\
\text { Twitter to interact with their } \\
\text { constituents }\end{array}$ & $\begin{array}{c}\text { Mixed } \\
\text { (Multiple } \\
\text { case study) }\end{array}$ & $\begin{array}{c}\text { Interviews, } \\
\text { participation and } \\
\text { observation in } \\
\text { meetings, twitter data } \\
\text { collection }\end{array}$ & $\begin{array}{l}2 \text { organizations (an } \\
\text { international } \\
\text { cooperative and a } \\
\text { multinational fast-food } \\
\text { chain) }\end{array}$ & Multiple \\
\hline $\begin{array}{l}\text { Boateng \& Okoe, } \\
\qquad 2015\end{array}$ & $\begin{array}{l}\text { Consumers' attitude } \\
\text { towards } \\
\text { social media advertising } \\
\text { and } \\
\text { their behavioural response }\end{array}$ & 49 & $\begin{array}{c}\text { Corporate } \\
\text { identity/ } \\
\text { organizational } \\
\text { image }\end{array}$ & Ghana & $\mathrm{NA}$ & $\begin{array}{l}\text { To examine the relationship } \\
\text { between consumers' attitude } \\
\text { toward social media advertising } \\
\text { and their behavioral response and } \\
\text { the moderating effect of } \\
\text { corporate reputation in this } \\
\text { relationship }\end{array}$ & Quantitative & $\begin{array}{l}\text { Survey research } \\
\text { design } \\
\text { (questionnaires, } \\
\text { hierarchical } \\
\text { regression) }\end{array}$ & Consumers & 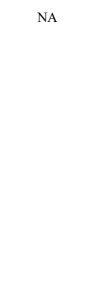 \\
\hline $\begin{array}{l}\text { Brandhorst \& } \\
\text { Jennings, } 2016\end{array}$ & $\begin{array}{l}\text { Fighting for funding: } \\
\text { Values advocacy and } \\
\text { Planned Parenthood's } \\
\text { right-to-life }\end{array}$ & 6 & $\begin{array}{l}\text { Organizational } \\
\text { image }\end{array}$ & USA & Health & $\begin{array}{l}\text { To examine how Planned } \\
\text { Parenthood appeals to core } \\
\text { American values through social } \\
\text { media to enhance its image and } \\
\text { reinforce its legitimacy }\end{array}$ & Qualitative & Rhetorical analysis & $\begin{array}{l}\text { Planned Parenthood (1 } \\
\text { organization) }\end{array}$ & Organization \\
\hline $\begin{array}{l}\text { Bruce \& Solomon, } \\
\qquad 2013\end{array}$ & $\begin{array}{l}\text { Managing for Media } \\
\text { Anarchy: A Corporate } \\
\text { Marketing Perspective }\end{array}$ & 35 & $\begin{array}{l}\text { Corporate } \\
\text { identity }\end{array}$ & $\mathrm{NA}$ & $\mathrm{NA}$ & $\begin{array}{l}\text { To propose a taxonomy of } \\
\text { "digital real estate" that } \\
\text { acknowledges an expansion in } \\
\text { the media options available to } \\
\text { managers }\end{array}$ & Conceptual & & $\mathrm{NA}$ & $\mathrm{NA}$ \\
\hline $\begin{array}{l}\text { Carpentier et al., } \\
2017\end{array}$ & $\begin{array}{l}\text { Recruiting nurses through } \\
\text { social media: Effects on } \\
\text { employer brand and } \\
\text { attractiveness }\end{array}$ & 8 & $\begin{array}{l}\text { Organizational } \\
\text { image }\end{array}$ & Belgium & Health & $\begin{array}{l}\text { To investigate whether and how } \\
\text { nurses' exposure to a hospital's } \\
\text { profile on social media affects } \\
\text { their perceptions of the hospital's } \\
\text { brand and attractiveness as an } \\
\text { employer }\end{array}$ & 更 & $\begin{array}{l}\text { Survey (online } \\
\text { questionnaire) }\end{array}$ & 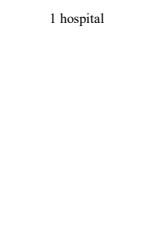 & Organization \\
\hline Dawson, 2018 & $\begin{array}{l}\text { Fans, Friends, Advocates, } \\
\text { Ambassadors, } \\
\text { and Haters: Social Media } \\
\text { Communities } \\
\text { and the Communicative }\end{array}$ & $\mathrm{NA}$ & $\begin{array}{l}\text { Organizational } \\
\text { identity }\end{array}$ & USA & $\begin{array}{l}\text { Several (for- profit and } \\
\text { non-profit sector) }\end{array}$ & $\begin{array}{l}\text { To demonstrate ways that } \\
\text { organizational identities are } \\
\text { co-authored from external } \\
\text { interaction (conversation) to } \\
\text { internal practice (text) }\end{array}$ & Qualitative & $\begin{array}{c}\text { Interviews, } \\
\text { marketing meetings } \\
\text { observations, and } \\
\text { social } \\
\text { media interaction }\end{array}$ & $\begin{array}{l}20 \text { diverse } \\
\text { organizations }\end{array}$ & Multiple \\
\hline
\end{tabular}




\begin{tabular}{|c|c|c|c|c|c|c|c|c|c|c|}
\hline & Constitution of & & & & & & & observations & & \\
\hline & Organizational Identity & & & & & & & & & \\
\hline \multirow[t]{7}{*}{ Devereux et al., 2017} & Corporate Identity and & 7 & Corporate & $\mathrm{NA}$ & $\mathrm{NA}$ & To explore the relationship & Conceptual & & $\mathrm{NA}$ & $\mathrm{NA}$ \\
\hline & Social Media: Existence & & identity & & & between social media and & & & & \\
\hline & and & & & & & corporate identity by breaking & & & & \\
\hline & Extension of the & & & & & social media use into five stages & & & & \\
\hline & Organization & & & & & and discussing what each stage & & & & \\
\hline & & & & & & can reveal and add to our & & & & \\
\hline & & & & & & knowledge of corporate identity & & & & \\
\hline \multirow[t]{7}{*}{ Di Lauro et all, 2018} & Measuring organizational & $\mathrm{NA}$ & Organizational & Italy & $\mathrm{NA}$ & To explore how data from & Quantitative & Linear regression & 1 organization & Organization \\
\hline & identity via Linkedn: The & & identity & & & employees' personal Linkedln & & (data collected from & & \\
\hline & role played by employes's & & & & & accounts can be used to measure & & Linkedin) & & \\
\hline & tenure, type of & & & & & how they manifest organizational & & & & \\
\hline & employment contract and & & & & & identity, and the roles that their & & & & \\
\hline & age & & & & & seniority of service, type of & & & & \\
\hline & & & & & & contract and age play in this & & & & \\
\hline \multirow[t]{6}{*}{ Foreman-Wernet, } & Reflections on Elitism: & 1 & Organizational & USA & Art & How arts organizations are & Mixed & Content analysis & Group of arts & Sector/ \\
\hline & What Arts Organizations & & identity & & & communicating their unique & & of annual reports, & organizations & Cluster/ \\
\hline & Communicate About & & & & & identities and how they are & & season brochures, & & Community \\
\hline & Themselves & & & & & working to position themselves & & news releases, and & & \\
\hline & & & & & & on the democratic side of the & & social media + case & & \\
\hline & & & & & & elitism continuum & & study approach & & \\
\hline \multirow[t]{5}{*}{ Giplin, 2010} & Organizational Image & 165 & Organizational & USA & Food & To examine the role of different & Quantitative & Case study (Social & 1 organization & Organization \\
\hline & Construction in a & & image & & & online and social media channels & & Network analysis) & (supermarket chain & \\
\hline & Fragmented & & & & & in & & & Whole & \\
\hline & Online Media & & & & & constructing organizational & & & Foods) & \\
\hline & Environment & & & & & image & & & & \\
\hline \multirow[t]{7}{*}{ Hanusch, 2017} & Political journalists' & 14 & Corporate (and & Australia, & Government & To address the lack of empirical & Quantitative & ANOVA & 679 accounts of & $\mathrm{NA}$ \\
\hline & corporate and personal & & personal) & Canada, & & understanding through an & & & parliamentary press & \\
\hline & identities on Twitter & & identity & New & & analysis of the identities which & & & gallery journalists & \\
\hline & profile pages: A & & & Zealand & & political journalists present on & & & & \\
\hline & comparative analysis in & & & and UK & & their Twitter profile pages & & & & \\
\hline & four & & & & & & & & & \\
\hline & Westminster democracies & & & & & & & & & \\
\hline \multirow[t]{7}{*}{ Holmegreen, 2015} & "Why am I to blame when & $\mathrm{NA}$ & Organizational & Denmark & Food & To discuss why social media & Qualitative & The data for the & 1 Organization & Organization \\
\hline & the law is on & & image & & & frames may exert substantial & & analysis consists of & (restaurant chain) & \\
\hline & my side?" A study of & & & & & influence on the image of & & entries from different & & \\
\hline & crises, public opinion and & & & & & organizations and even trigger & & social-media sites & & \\
\hline & frames & & & & & organizational crises & & and articles from & & \\
\hline & & & & & & & & Danish online and & & \\
\hline & & & & & & & & print media & & \\
\hline \multirow[t]{4}{*}{ Huang-Horowitz \& } & Bridging organizational & 10 & Organizational & $\mathrm{NA}$ & $\mathrm{NA}$ & To propose a conceptual model & Qualitative & Reviews & $\mathrm{NA}$ & $\mathrm{NA}$ \\
\hline & identity and reputation & & identity & & & that can be used to bridge & & & & \\
\hline & messages online: a & & & & & organizational identity and & & & & \\
\hline & conceptual model & & & & & reputation messages & & & & \\
\hline \multirow[t]{3}{*}{ Hussain, 2015} & The impact of social & 1 & Organizational & South & Sport & Set out to assess the impact of & Quantitative & Survey & 1 organization (local & Organization \\
\hline & media within the sporting & & image & Africa & & social media communication & & (questionnaire) & rugby sport & \\
\hline & industry & & & & & tools within the sporting industry & & & organization) & \\
\hline \multirow[t]{6}{*}{ Joachim et al., 2018} & Twittering for talent: & 6 & Corporate & USA & Military and security & To examine how private military & Qualitative & Computer content & 2 organizations (Private & Sector/ \\
\hline & Private military and & & identity & & & and security companies deploy & & analysis & military and security & Cluster/ \\
\hline & security companies & & & & & these identities when they recruit & & & companies) & Community \\
\hline & between business and & & & & & new personnel through social & & & & \\
\hline & military & & & & & media & & & & \\
\hline & branding & & & & & & & & & \\
\hline \multirow[t]{2}{*}{ Madsen, 2016} & Constructing & 21 & Organizational & Denmark & Bank & How coworkers use internal & Qualitative & Case study & 1 organization & Organization \\
\hline & Organizational & & identity & & & social media to contribute to the & & (ethnographic & (coworkers at a large & \\
\hline
\end{tabular}




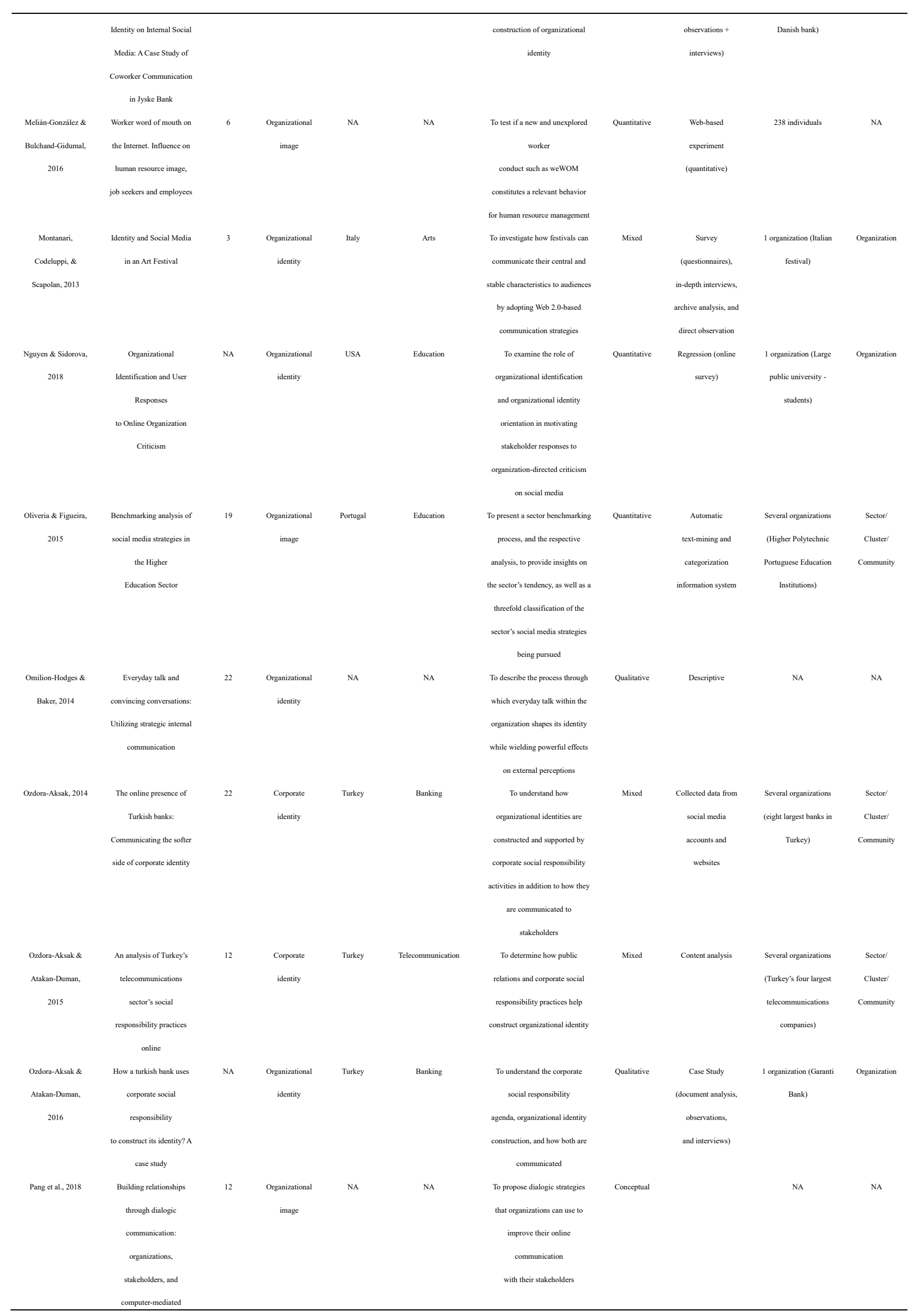




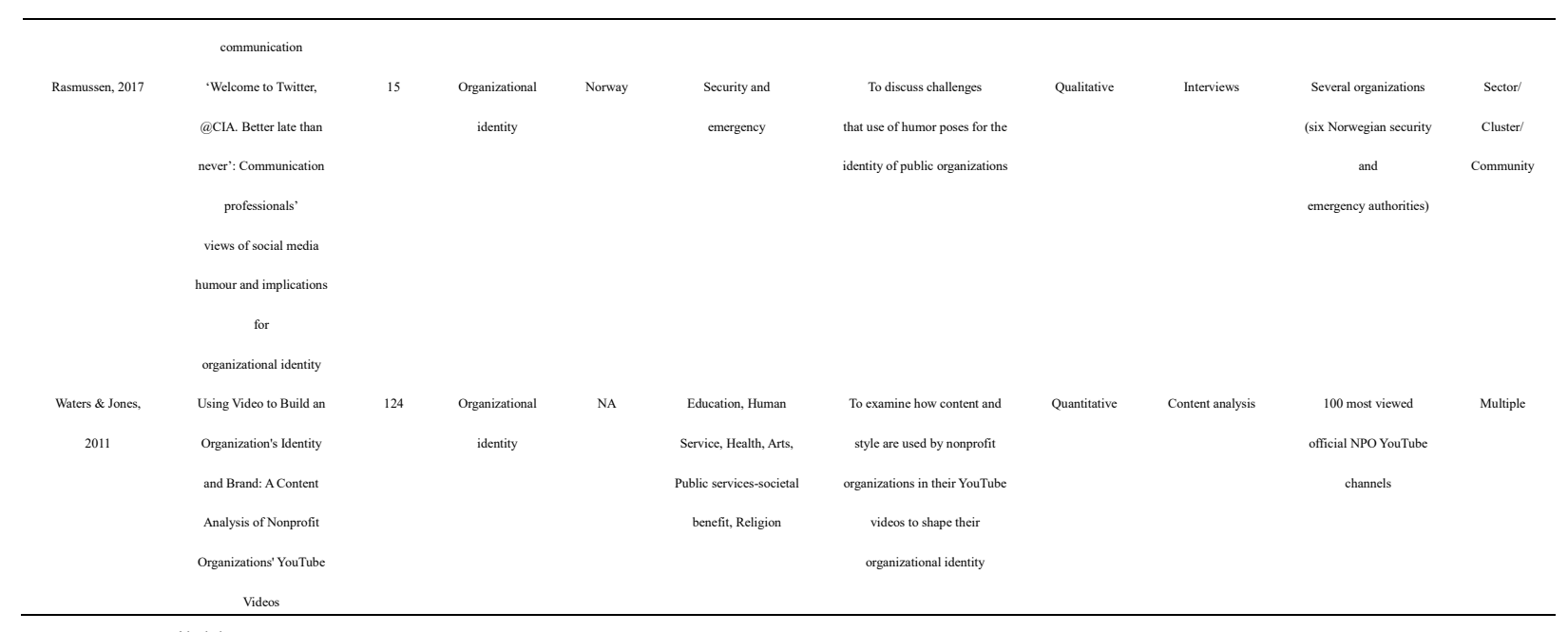

NA=Not available.

\section{Copyrights}

Copyright for this article is retained by the author(s), with first publication rights granted to the journal.

This is an open-access article distributed under the terms and conditions of the Creative Commons Attribution license (http://creativecommons.org/licenses/by/4.0/). 